\title{
BERMAIN SEBAGAI KEBUTUHAN DAN STRATEGI PENGEMBANGAN DIRI ANAK
}

\author{
Anita Yus \\ e-mail: anitayus@ymail.com \\ PG PAUD Universitas Negeri Medan
}

\begin{abstract}
Abstrak: Bermain bagian dari kehidupan anak. Dalam bermain anak mengeksplor dan menyadari dunianya. Bermain dapat terjadi di mana dan kapan saja. Konteks, tempat dan waktu akan memunculkan bentuk, aktivitas dan isi permainan. Ketika bermain, anak belajar membuat rencana, fokus berlatih pada tugas tertentu, memecahkan masalah, dan mengekspresikan ide-ide yang dimilikinya. Bermain dapat dirancang dan digunakan sebagai strategi pengembangan diri anak. Aktivitas-aktivitas belajar yang diharapkan dilakukan anak dirangkai dalam satu kegiatan bermain. Situasi ini akan memudahkan anak memperoleh pengetahuan dan pengalaman baru.
\end{abstract}

Kata-kata kunci: bermain, kebutuhan, strategi, pengembangan diri, dan kegiatan belajar.

\section{PLAYING GAMES AS A NEED AND STRATEGY OF CHILDREN SELF DEVELOPMENT}

\begin{abstract}
Playing games is a part of the children's life. In playing games the children are exploring and understanding their world. This article discusses how playing games can be used in children's education. The children can play anywhere and anytime they want. The context, place, and time will determine the forms, activities, and game content. In playing games, the children plan, concentrate on doing certain tasks, solve problems, and express their ideas. This article concludes that playing games can be designed and used as a strategy of the children self development. Learning activities to be done by the children are integrated in playing activities. These activities facilitate the children to gain new knowledge and experience.
\end{abstract}

Keywords: playing games, need, strategy, children selfdevelopment.

\section{PENDAHULUAN}

Banyak ahli sepakat bahwa dunia anak sangat lekat dengan bermain. Bahkan bermain dinyatakan sebagai bagian dan apa yang dilakukan anak dalam kehidupannya. Bermain merupakan situasi yang menyenangkan dan sangat bermanfaat bagi perkembangan anak. Hal ini dapat dilihat dari daya tahun dan ketekunan anak bermain yang seakan-akan tiada lelahnya serta dari ekspresi wajah yang senang.

Berbagai alat dan situasi di lingkungan anak dapat digunakan sebagai media dan alat bermain. Meja, kursi, perhiasan rumah, alat masak, dan yang lainnya dapat digunakan sebagai media bermain. Dengan kata lain, anak bermain tidak hanya dengan menggunakan alat bermain yang telah disediakan. Apa saja yang ada di dekat anak dapat digunakan untuk bermain.

Bermain juga dapat dikondisikan. Lingkungan dapat dirancang untuk berbagai permainan dalam membantu percepatan aspek perkembangan tertentu. Misalnya, bila menginginkan anak berlatih fisik, melompat, memanjat, dan lainnya; lingkungan dapat menyediakan alat yang berkenaan dengan memanjat, melompat, dan Isebagainya.

Lembaga Pendidikan Anak Usia Dini (PAUD), yaitu Taman Kanak-kanak (TK), Raudhatul Athfal (RA), Kelompok Bermain (Kober), Taman Pengasuhan Anak (TPA) memberi layanan pendidikan melalui berbagai kegiatan belajar. Pernyataan 'belajar sambil bermain, bermain seraya belajar' sebagai slogan yang lancar diucapkan para guru di lembaga PAUD perlu dipertanyakan dalam praktiknya. Pertanyaan yang muncul adalah apakah layanan pendidikan yang diberikan sudah dilakukan seperti slogan yang lancar diucapkan itu.

Isu krusial di PAUD dewasa ini adalah adanya kecenderungan salah kaprah dalam penyelenggaraan 
pendidikan (Dedi, 2004). Salah satu kritik terhadap pembelajaran di Taman Kanak-kanak adalah sebagai miniatur Sekolah Dasar. Hasil angket yang diberikan pada Guru TK saat PLPG menunjukkan bahwa kegiatan akademik (baca tulis menggunakan lembar kerja) mendominasi kegiatan belajar rata-rata sebesar $70 \%$. Berarti kegiatan bermain hanya sekitar $30 \%$ diperoleh anak. Bila kondisi tersebut dialami anak selama menjalani kegiatan belajar di PAUD, apakah yang akan terjadi pada perkembangan anak?

Bermain sebagai suatu kebutuhan sekaligus sebagai pendekatan, strategi, kegiatan, dan metode belajar anak (Wolfgang, 1981). Bagaimana menerapkan bermain sebagai pendekatan, strategi, kegiatan dan metode belajar di PAUD? Artikel ini mengkaji bermain sebagai kebutuhan dan strategi pengembangan diri anak dalam pembelajaran di PAUD.

\section{PEMBAHASAN}

\section{Pengertian dan Karakteristik Bermain}

Bermain memberi peluang bagi anak untuk melakukan berbagai hal (eksplorasi). Situasi itulah yang membuat anak menemukan sesuatu yang bermanfaat bagi perkembangan dirinya. Situasi tersebut dapat dinyatakan sebagai situasi anak belajar. Artinya, bermain merupakan cara anak belajar tentang apa saja, seperti belajar tentang objek, kejadian, situasi, dan konsep (misalnya halus, kasar, dan lainlain). Anak berlatih kordinasi berbagai otot gerak, misalnya otot jari. Anak juga berlatih mencari sebab akibat dan memecahkan masalah. Selain itu, melalui bermain, anak berlatih mengekspresikan perasaan, dan berusaha mendapatkan sesuatu.

Beberapa ahli psikologi memberi pandangan mereka tentang bermain. Bermain merupakan proses penyiapan diri untuk menyandang peran sebagai orang dewasa (Groos dalam Hyun, 1998). Bermain akan membangun kembali energi yang hilang sehingga diri mereka segar kembali (Lazarus dalam Hyun, 1998). Bermain merupakan wahana untuk menggunakan energi yang berlebih sehingga anak terlepas dari tekanan (Schiller \& Spencer).

Bermain dapat terjadi di mana saja. Tempat dan konteks bermain dapat memunculkan bentuk, aktivitas, dan isi permainan. Ada yang berbeda di antara ketiganya. Namun, ada juga yang sama walau nama yang digunakan dalam permainan tersebut berbeda.

Bermain dilakukan anak sesuai dengan tingkat perkembangan anak. Dengan kemampuan yang telah dimilikinya, bermain akan terjadi begitu saja tanpa skenario yang mengikat. Anak bebas melakukan berbagai hal dalam permainan yang dilakukannya. Tidak ada paksaan bagi anak harus melakukan sesuatu dalam bermain.

Dari beberapa pandangan yang telah dikemukakan di atas dapat dinyatakan bahwa bermain merupakan proses belajar, baik disadari anak atau tidak anak telah belajar sesuatu yang berguna bagi kehidupannya. Dengan demikian, dapat dinyatakan bahwa bermain bagi anak sangat besar manfaatnya. Bermain berguna untuk mengembangkan diri anak.

Berdasarkan batasan dan pandangan bermain yang telah dikemukakan dapat dinyatakan bahwa bermain memiliki karakteristik sebagai berikut: (a) bermain sebagai simbolis, (b) memiliki penuh makna, (c) bermain sebagai aktivitas, (d) bermain sebagai sesuatu yang menyenangkan, (e) bermain dilakukan atas kemauan sendiri (sukarela), (f) bermain sebagai rule-governed, dan (g) bermain sebagai aktivitas satu episode. Dengan mengetahui ketujuh karakteristik tersebut dapat dinyatakan bahwa tidak semua aktivitas adalah permainan, dan tidak semua pengalaman yang penuh arti melibatkan permainan. Bagaimana pun, masing-masing dari unsur-unsur itu menentukan karakter permainan.

\section{Pentingnya Bermain Bagi Perkembangan Anak}

Bermain memberi kontribusi yang signifikan terhadap perkembangan anak. Ketika bermain, anak akan mempelajari dan menyerap segala sesuatu yang terjadi di lingkungan sekitarnya (Montessori dalam Sudono, 2000). Pendapat tersebut mengisyaratkan bahwa terjadi proses perkembangan pada diri anak ketika anak bermain, yaitu melalui proses mempelajari dan menyerap. Selain itu, setiap benda yang dimainkan berfungsi sesuai dengan imajinasi anak (Frobel dalam Sudono, 2000). Melalui imajinasinya, anak akan memperoleh konsep-konsep bahasa, seperti 'sama' atau 'lain'. Kalau itu terjadi pada diri anak, berarti anak belajar. Dua pendapat yang telah dikemukakan menunjukkan bahwa bermain membuka jalan untuk mencapai perubahan dalam bentuk pengetahuan dan kemampuan.

Teori Piaget (1962) menjelaskan bahwa bermain bukan saja mencerminkan tahap perkembangan anak, tetapi juga memberikan sumbangan terhadap perkembangan kognisi itu sendiri. Lebih lanjut Piaget menjelaskan bahwa Perkembangan bermain berkaitan dengan perkembangan kecerdasan seseorang. Sejalan dengan Piaget, Vygotsky menekankan 
bahwa bermain mempunyai peran langsung terhadap perkembangan kognisi seorang anak. Menurut Vygotsky seorang anak belum dapat berpikir abstrak karena bagi mereka makna dan objek menjadi satu. Melalui bermain ia akan dapat memisahkan makna dengan objek sebenarnya. Dengan demikian, bermain merupakan proses self help tool. Keterlibatan anak dalam kegiatan bermain memberi peluang untuk memperoleh kemajuan dalam perkembangannya bahkan memajukan zone of proximal development (ZPD) sehingga mencapai tingkatan yang lebih tinggi dalam mengfungsikan kemampuannya.

Selain dua tokoh yang dikemukakan di atas, masih banyak tokoh yang lain yang membahas bermain dalam kehidupan anak. Secara ringkas, dapat dikemukakan kaitan bermain dengan perkembangan anak menurut beberapa tokoh, yaitu Piaget dengan teori kognitifnya menekankan bahwa peran bermain lebih ditujukan untuk mempraktekkan dan melakukan konsolidasi konsep-konsep serta keterampilan yang telah dipelajari sebelumnya. Vygotsky dengan teori kognitifnya lebih menekan peran bermain pada mengembangkan berpikir abstrak, belajar dalam kaitan ZPD, dan pengaturan diri. Bruner masih dengan teori kognitifnya memusatkan peran bermain pada perkembangan imajinasi dan narasi.

Berdasarkan uraian yang dikemukakan dapat ditegaskan bahwa tidak ada alasan untuk membantah pernyataan 'bermain sangat berarti bagi perkembangan anak'. Anak akan mencoba, merasakan, mencari, menemukan sehingga diperoleh sesuatu yang baru dari akvitas dalam bermain. Temuan-temuan itu memberi nilai tambah bagi perkembangan anak.

Lebih lanjut tentang teori bermain dijelaskan oleh Piaget dan Vygotsky berdasarkan tahapan perkembangan. Piaget dan Vygotsky melihat tahapan perkembangan anak terdiri dari tahapan sensori motor, praoperasional, dan konkrit operasional. Tahapan tersebut memiliki satu karakteristik bermain sendiri. Dalam permainan terdapat kaitan antara aktivitas, fisik, alat permainan, orang-orang lain, yang terlibat baik secara fisik maupun psikhis. Pandangan Piaget tentang proses akomodasi dan asimilasi juga mendasari teori bermain yang dikemukakannya.

Piaget mengidentifikasi tahap perkembangan dengan permainan. Permainan fungsional dihubungkan dengan sensorimotor, simbolik berkaitan dengan praoperasional, dan aturan bermain berkaitan dengan konkrit operasional.

Permainan fungsional dinyatakan juga sebagai mempraktekkan permainan yang di dalamnya terdapat dua hal, yaitu tindakan dan objek tindakan.
Dalam perkembangan anak berikut permainan ini akan berkembang lebih bervariatif sesuai dengan perkembangan kemampuan anak yang berada pada praoperasional. Tindakan dan objek permainan semakin komplek baik dari sisi jumlah, jenis, dan penggunaannya.

Pada tahap praoperasional konkrit, anak mulai menggunakan symbol-simbol dalam bermain. Dalam bermain, anak mulai menirukan peran tertentu. Anak akan menirukan peran orang-orang disekitar atau yang diketahui walaupun kadang terjadi modifikasi atau perubahan dalam memainkan peran tersebut.

Pada tahap operasi-operasi konkrit anak, bermain dengan menunjukan adanya kombinasi dalam berbagai aktivitas, baik fisik maupun bahasa. Mulai kelihatan bentuk-bentuk abstrak dalam permainan yang dilakukannya.

Vygotsky menyatakan bahwa bermain adalah cara untuk membantu diri anak sendiri. Dengan bermain, zona of proximal development (ZPD) dilengkapi dengan scaffolding akan memperoleh stimulus sehingga akan meningkatkan mencapai potential development. Dalam bermain anak akan berlatih mengendalikan dirinya karena bermain dikontrol oleh imajiner anak sendiri. Anak dapat berpura-pura menangis dan tiba-tiba menghentikan tangisannya. Vygotsky juga mejelaskan bahwa bermain semua potensi anak akan berkembang, karena bermain umumnya berkaitan dengan kehidupan nyata/sehari-hari.

Terdapat lima tahapan perkembangan bermain yang sekaligus sebagai kebutuhan (Mildred, 1935). Tahapan perkembangan yang dimaksud terdiri dari bermain (1) solitaire, (2) parallel, (3) onlooker, (4) associative, dan (5) cooperative. Pada tahap bermain solitaire, anak akan bermain sendiri. Anak bermain dengan menggunakan bagian tubuhnya, seperti tangan dan kaki. Tahapan bermain ini, umumnya terjadi pada saat usia kelender lahir sampai 1 tahun. Tahap kedua, adalah bermain onlooker. Pada tahap ini anak hanya melihat atau sebagai pengamat anak lain yang bermain. Anak tekun memperhatikan tanpa terlibat dalam permainan. Tahap ketiga adalah bermain paralel. Pada tahap ini anak bermain bersama dengan anak yang lain dengan berdampingan tanpa berkomunikasi atau keterikatan permainan. Pada tahap keempat adalah bermain assosciatif, yaitu beberapa anak bermain bersama-sama namun belum bekerja sama. Pada tahap kelima anak berada pada tahap bermain cooperative. Pada masa ini anak bermain bersama dan bekerja sama saling membantu untuk menyelesaikan kegiatan bermain bersama. 


\section{Bermain dan Kegiatan Pengembangan}

Ada beberapa kegiatan pengembangan yang perlu dilakukan di lembaga PAUD untuk membantu perkembangan anak. Dengan mengacu kepada standar penyelenggaraan PAUD yang tertera dalam Permendiknas Nomor 58 Tahun 2009 terdapat lima lingkup pengembangan, yaitu (1) nilai agama dan moral, (2) kognitif, (3) fisik motorik, (4) bahasa, dan (5) sosial emosional. Kegiatan bermain ditujukan untuk mengembangkan semua lingkup pengembangan yang diidentifikasi tersebut.

Di antara kegiatan bermain yang berkaitan dengan kegiatan pengembangan, yaitu bermain sosial bagi anak usia prasekolah dapat menekan rasa ego anak (Tedjasaputra, 2001). Situasi tersebut memberi peluang kepada anak untuk mngembangkan kemampuan menyesuaikan diri dengan orang lain dan situasi yang ada.

Bermain sosial dimaksudkan untuk melatih anak berhubungan dengan orang lain. Anak akan dapat mengenal orang lain dan berbagai kegiatan dengan orang lain sebagai pasangan bermainnya. Bermain sosial dilakukan oleh paling sedikit dua orang anak. Bermain sosial penting bagi perkembangan anak, terutama karena (a) memberi peluang kepada anak untuk mengenal orang lain, (b) mengembangkan kemampuan anak berkomunikasi, (c) melatih anak bersosialisasi, dan (d) membantu anak menjalin persahabatan. Secara khusus, bermain sosial memberi kontribuasi terhadap perkembangan kemampuan, yaitu: (a) bekerja sama, (b) suka menolong, (c) mau berbagi, (d) bermain bersama teman, guru dan orangtua, (e) menghargai orang lain, (f) menghargai hasil karya dirinya dan orang lain, serta $(\mathrm{g})$ memberi kontribusi pada kelompok.

Kegiatan bermain lainnya adalah bermain keterampilan. Bermain keterampilan dapat dilaksanakan dengan memperhatikan beberapa hal, yaitu: (a) tidak terburu-buru walaupun harus siap untuk melakukan sesuatu, (b) adanya perubahan suasana/tempat, (c) berikan sesuatu pada anak, (d) beri kesempatan anak sendiri, dan (e) dukung anak untuk mengatasi keterbatasannya. Dengan memperhatikan kondisi tersebut, anak dapat siap melakukan kegiatan bermain keterampilan. Anak dapat bermain menggunakan kipas-kipasan yang dibuat dari kertas dan berputar jika anak yang memegang bergerak dan atau kipas ditiup angin. Ketepatan memegang kipas-kipasan ke arah angin merupakan suatu keterampilan yang harus dilatih untuk dimiliki anak.

Terdapat berbagai bentuk dan jenis permainan yang dapat digunakan dalam bermain keterampilan. Ada permainan yang harus digerakkan terus baru bergerak, ada yang disentuh sedikit saja sudah bergerak.

Bermain teka-teki dapat dilakukan anak dengan berbagai cara. Bermain teka-teki bermanfaat bagi perkembangan anak, khususnya untuk (1) mengembangkan keterampilan berpikir anak, (2) menimbulkan rasa ingin tahu anak, dan (3) membangun kemandirian anak (Jeffree, McConkey \& Hewson, 1988)

Bermain teka-teki dapat dilakukan secara verbal dan atau menggunakan alat. Misalnya, kepada anak diberikan pernyataan seperti, "ia di pakai di kaki" atau kepada anak diberikan beberapa potongan dari suatu bentuk yang dapat disusun kembali menjadi suatu bentuk. Anak diminta untuk menyusun potonganpotongan benda tersebut.

Pada anak di daerah (Indonesia) bermain teka-teki dapat dilakukan dengan menggunakan guli, batu, atau apa saja. Anak diminta menebak berapa banyak benda yang disimpan, atau anak diminta untuk menebak ada pada siap benda yang tadi dilihat setelah ia menutup mata (dalam permainan daerah, seperti cublek-cublek sueng). Permainan ini dilakukan dalam situasi gemibira dan bahkan dapat diiringi nyanyian. Anak bersama-sama bernyanyi sambil melakukan aktivitas sesuai dengan bentuk teka-teki yang diberikan.

bermain teka-teki pada dasarnya dapat dilakukan pada anak usia sekitar satu sampai dengan delapan tahun. Hal yang perlu diperhatikan adalah tingkat kesulitan teka-tekinya. Anak-anak yang masih sangat kecil diminta atau diberi tebakan yang sangat sederhana, misalnya ada pada siapa benda yang tadi ditunjukkan. Kalau membuat bangunan tentu alat yang digunakan harus sesuai ukurannya dengan kondisi fisik anak.

Permainan teka-teki melalui menyusun bangunan di dalamnya terdapat umsur kebebasan dan berkreasi. Anak bebas menyusun dalam berbagai bentuk. Bila ini dilakukan berulang kali akan memunculkan kreasi bentuk yang baru. Dengan demikian, permainan ini dapat mengembangkan kreativitas anak.

Permainan maze dan puzzle juga termasuk dalam kelompok permainan teka-teki (Jeffree, McConkey, \& Hewson, 1988). Permainan sudah lebih terikat menggunakannya dibanding dengan alat untuk menyusun. Anak sudah harus mengikuti aturan dari maze atau puzzle yang digunakan. Pada bentuk permainan ini lebih mengasah ketepatan dan keterampilan berpikir anak. 


\section{Praktek Bermain Dalam Pembelajaran AUD}

Hasil penelitian Anita (2008) menunjukkan bahwa praktek bermain di TK, RA, KB masih belum terintegrasi dengan kegiatan belajar. Kegiatan bermain masih dilakukan secara terpisah. Contohnya, anak yang dapat menyelesaikan 'tugasnya', misalnya menggambar, mewarnai, menulis huruf/angka atau membentuk ka'bah dari kotak bekas teh baru diberi kesempatan bermain puzzle, plastisin, meronce, atau yang lainnya.

Sebenarnya kegiatan bermain harus menjadi satu kesatuan dan sebagai strategi pembelajaran. Semua aktivitas belajar dirangkai dalam kegiatan bermain. Salah satu contoh praktek bermain dalam pembelajaran dikemukakan berikut ini.

Tema : Biji-Bijian

Nama kegiatan : Membuat Hiasan

Kelompok : B

Alasan menggunakan "Biji-bijian"

- Kaya informasi

- Menarik untuk digunakan dengan berbagai kegiatan

- Untuk memotivasi, merangsang minat anak untuk belajar dan mengembangkan konsep terkait bijibijian, khususnya:

- Semua yang tumbuh berasal dari sejenis benih (biji)

- Biji beragam dalam warna, ukuran, bentuk, tekstur

- Biji membutuhkan beberapa hal untuk bertumbuh

- Kita memakan biji-bijian

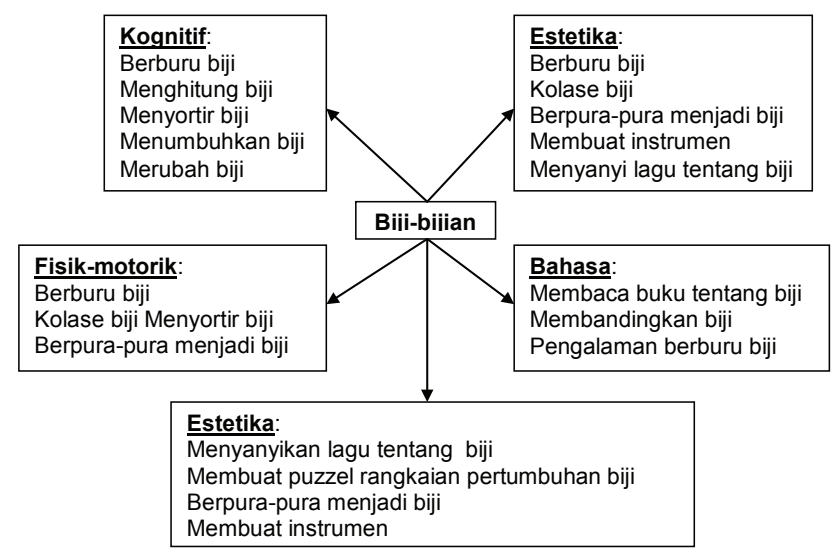

Gambar 1. Bagan kegiatan dalam Webing

Tabel 1. Rancangan Kegiatan Mingguan

\begin{tabular}{|c|c|c|c|c|c|c|}
\hline Pert & Konsep & Kognitif & Bahasa & Fisik-motorik & Seni & Sosial-emosional \\
\hline 1 & Ragam Biji & $\begin{array}{l}\text { Memahami konsep } \\
\text { sains sederhana: } \\
\text { pertumbuhan } \\
\text { tanaman dari biji. }\end{array}$ & $\begin{array}{l}\text { Pra membaca, } \\
\text { memiliki } \\
\text { perbendaharaan } \\
\text { kata yang diperlukan } \\
\text { untuk berkomunikasi } \\
\text { sehari-hari. }\end{array}$ & $\begin{array}{l}\text { Menggerakkan } \\
\text { jari tangan: } \\
\text { lentur, kekuatan } \\
\text { otot, koordinasi }\end{array}$ & $\begin{array}{l}\text { Mencipta dengan } \\
\text { media : kertas } \\
\text { gambar, alat tulis/ } \\
\text { gambar. }\end{array}$ & Kerjasama \\
\hline 2 & Ragam Biji & $\begin{array}{l}\text { Memahami ukuran: } \\
\text { membedakan } \\
\text { berat, mengisi, dan } \\
\text { menyebutkan isi } \\
\text { wadah. }\end{array}$ & $\begin{array}{l}\text { Memiliki } \\
\text { perbendaharaan } \\
\text { kata yang diperlukan } \\
\text { untuk berkomunikasi } \\
\text { sehari-hari. }\end{array}$ & $\begin{array}{l}\text { Menggerakkan } \\
\text { lengan untuk } \\
\text { kelenturan, } \\
\text { kekuatan, dan } \\
\text { koordinasi }\end{array}$ & $\begin{array}{l}\text { a) Mencipta dengan } \\
\text { media: membuat } \\
\text { bunyi/perkusi } \\
\text { b) Mengekspresikan } \\
\text { diri dalam gerak } \\
\text { c) Menyanyi dan } \\
\text { memainkan alat } \\
\text { musik perkusi. }\end{array}$ & $\begin{array}{l}\text { Rasa percaya } \\
\text { diri: membuat } \\
\text { keputusan } \\
\text { sederhana, } \\
\text { menyampaikan } \\
\text { pengetahuan, } \\
\text { mandiri membuat } \\
\text { perkusi. }\end{array}$ \\
\hline 3 & Kegunaan biji & $\begin{array}{l}\text { a) Memahami benda } \\
\text { sesuai bentuk, jenis, } \\
\text { ukuran. } \\
\text { b) Memahami konsep } \\
\text { sains sederhana: } \\
\text { perubahan wujud } \\
\text { karena proses } \\
\text { pemanasan. }\end{array}$ & $\begin{array}{l}\text { Memiliki } \\
\text { perbendaharaan } \\
\text { kata yang diperlukan } \\
\text { untuk berkomunikasi } \\
\text { sehari-hari. }\end{array}$ & $\begin{array}{l}\text { Menggerakkan } \\
\text { jari tangan: } \\
\text { lentur, kekuatan } \\
\text { otot, koordinasi. }\end{array}$ & $\begin{array}{l}\text { Mencipta dengan } \\
\text { media: kolase biji- } \\
\text { bijian. }\end{array}$ & $\begin{array}{l}\text { Rasa percaya diri: } \\
\text { menyampaikan } \\
\text { pengetahuan, } \\
\text { mandiri membuat } \\
\text { kolase. }\end{array}$ \\
\hline 4 & $\begin{array}{l}\text { Pertumbuhan } \\
\text { biji }\end{array}$ & $\begin{array}{l}\text { a) Memahami konsep } \\
\text { sequencing (urutan } \\
\text { peristiwa). } \\
\text { b) Memahami konsep } \\
\text { sains sederhana: } \\
\text { pertumbuhan } \\
\text { tanaman dari biji. }\end{array}$ & $\begin{array}{l}\text { Memiliki } \\
\text { perbendaharaan } \\
\text { kata yang diperlukan } \\
\text { untuk berkomunikasi } \\
\text { sehari-hari. }\end{array}$ & $\begin{array}{l}\text { Menggerakkan } \\
\text { jari tangan: } \\
\text { lentur, kekuatan } \\
\text { otot, dan } \\
\text { koordinasi. }\end{array}$ & $\begin{array}{l}\text { Mengekspresikan } \\
\text { dalam gerak: } \\
\text { gerakan "popcorn" } \\
\text { mengikuti irama } \\
\text { musik }\end{array}$ & $\begin{array}{l}\text { Kerjasama: } \\
\text { membuat } \\
\text { puzzle urutan } \\
\text { pertumbuhan biji. }\end{array}$ \\
\hline 5 & $\begin{array}{l}\text { Menumbuhkan } \\
\text { biji }\end{array}$ & $\begin{array}{l}\text { Memahami konsep } \\
\text { sains sederhana: } \\
\text { pertumbuhan } \\
\text { tanaman dari biji. }\end{array}$ & $\begin{array}{l}\text { Memiliki } \\
\text { perbendaharaan } \\
\text { kata yang diperlukan } \\
\text { untuk berkomunikasi } \\
\text { sehari-hari. }\end{array}$ & $\begin{array}{l}\text { Menggerakkan } \\
\text { tubuh: } \\
\text { kelenturan } \\
\text { tubuh. }\end{array}$ & $\begin{array}{l}\text { Menyanyi "Tanam } \\
\text { jagung” } \\
\text { Ekspresi gerak } \\
\text { pertumbuhan. }\end{array}$ & $\begin{array}{l}\text { Disiplin \& } \\
\text { bertanggungjawab: } \\
\text { memeriksa } \\
\text { pertumbuhan } \\
\text { kacang hijau } \\
\text { setiap hari. }\end{array}$ \\
\hline
\end{tabular}




\section{PENUTUP}

\section{Kesimpulan}

Bermain merupakan kegiatan menyenangkan yang dapat mendorong anak bereksplorasi dan bereksperimen, sehingga anak memperoleh pengalaman yang dapat membantu perkembangan dirinya. Oleh karena itu, kegiatan bermain menjadi penting bagi perkembangan dan belajar anak. Praktek bermain dapat dirancang sesuai dengan kebutuhan perkembangan dan belajar anak.

\section{DAFTAR PUSTAKA}

Dedi, S. (2004). Membangun bangsa melalui pendidikan. Bandung: PT Remaja Rosdakarya.

Dockett, S. \& Marilyn. Fleer. (1999). Play and pedagogy in early childhood: Bending the rules. Harcourt.

Hyun, E. (1998). Culture and development in children's play. New York: Peter Lang.

Mildred, B. Patren. (1935). Social play among preschool children. New York: Herron \& B SuttonSmith (eds)
Piaget, J. (1962). Play, dreams, and imitation in childhood. New York: W. W. Norton.

Sudono, Anggani. (2000). Sumber belajar dan alat permainan dalam pendidikan anak usia dini. Jakarta: Grasindo.

Tedjasaputra, Mayke.S. (2001). Bermain, mainan dan permainan. Jakarta: Grasindo.

Yus, A. (2008). Profil dan permasalahan pembelajaran di lembaga PAUD Kota Medan. Laporan Penelitian, Medan: Universitas Negeri Medan 